\title{
Geochemistry and petrogenesis of Neoproterozoic Mylliem granitoids, Meghalaya Plateau, northeastern India
}

\author{
Jyotisankar RAY ${ }^{1}$, ABhishek SAHA ${ }^{1, *}$, Sohini Ganguly ${ }^{1}$, \\ V BAlARAM $^{2}$, A Keshav Krishna ${ }^{2}$ and SAmpa Hazra ${ }^{1}$ \\ ${ }^{1}$ Department of Geology, University of Calcutta, 35, Ballygunge Circular Road, Kolkata 700 019, India. \\ ${ }^{2}$ Geochemistry Division, National Geophysical Research Institute, Uppal Road, Hyderabad 500 606, India. \\ *e-mail: asaha.geocal@gmail.com
}

The Mylliem granitoids of the Meghalaya Plateau, northeastern India, represent one of the disharmonic Neoproterozoic igneous plutons, which are intrusive into low-grade Shillong Group of metasediments. Field studies indicate that the Mylliem granitoids cover an area of about $40 \mathrm{~km}^{2}$ and is characterized by development of variable attitude of primary foliations mostly marked along the margin of the pluton. Xenoliths of both Shillong Group of metasediments and mafic rocks have been found to occur within Mylliem granitoids. Structural study of the primary foliation is suggestive of funnel-shaped intrusion of Mylliem granitoids with no appreciable evidence of shearing. Petrographically, Mylliem granitoids are characterized by pink to white phenocrysts of prismatic microcline/perthite and lath-shaped plagioclase $\left(\mathrm{An}_{20}-\mathrm{An}_{29}\right)$. Groundmass material is characterized by quartz, microcline, plagioclase, muscovite and biotite. Sphene and apatite occur as accessory minerals. Petrographically Mylliem granitoids have been discriminated as granite and granodiorite according to IUGS system of classification.

Critical evaluation of geochemical data and variation trends of major oxides/trace elements suggests a significant role of fractional crystallization in the evolution of Mylliem pluton. Th/U ratios (3.22-6.77) indicate a relatively higher abundance of Th over U. Chondrite-normalized REE diagram characteristically shows an enriched LREE pattern and prominent negative $\mathrm{Eu}$ anomaly $(\mathrm{Eu} / \mathrm{Eu}=0.16-0.42)$ indicating the significant role of plagioclase fractionation from the parent magma. An overall strong REE fractionation pattern has been envisaged for Mylliem granitoids. The strong REE fractionation of the Mylliem granitoids is depicted by $(\mathrm{Ce} / \mathrm{Yb})_{N}$ values, which show a range of 1.39 to 1.65 . The aluminium saturation index (ASI) (ranging from 1.0 to 1.3), A/CNK ratios (ranging from 1.4 to 2.11) and $\mathrm{A} / \mathrm{NK}$ ratios (ranging from 1.75 to 2.43 ) provide evidences for the peraluminous, S-type nature of the Mylliem granitoids. The peraluminous, S-type character is further supported by geochemical parameters such as Fe* and MALI (modified alkali lime index). Normative corundum $>1.0 \mathrm{wt} . \%$ is suggestive of the S-type nature of Mylliem granitoids. This is indicative of parent melt-extraction from metasedimentary source rocks by partial melting. Distinct geochemical parameters suggest a post-orogenic tectonic environment for the Mylliem granitoids. The peraluminous, calc-alkalic to alkali-calcic, post-orogenic Mylliem granitoids are geochemically correlatable with the post-orogenic Caledonian granitoids of Ireland and Britain.

Keywords. Mylliem granitoids; northeastern India; peraluminous; post-orogenic; Caledonian. 


\section{Introduction}

The Archaean basement gneisses and Mesoproterozoic granulites (Chatterjee et al 2007) and the Shillong Group of metasediments of the Meghalaya Plateau have been impregnated with disharmonic emplacements of several granitoid plutons (Mazumdar 1976; Acharyya et al 1986; Ghosh et al 1994). These syn- to late-tectonic granitoids straddle the entire Precambrian regime of the Meghalaya Plateau and Mikir Hills in north-eastern India and range in age from 479 to 881 Ma (Nandy 2001; Ghosh et al 2005). South Khasi batholith (690 $\pm 26 \mathrm{Ma})$, Mylliem pluton $(607 \pm 13 \mathrm{Ma})$, Kyrdem pluton $(479 \pm 26 \mathrm{Ma})$ and

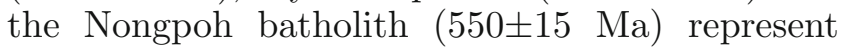
a few significant porphyritic granitoids of the east-central Meghalaya Plateau, broadly becoming younger in age from south-west to north-east (Ghosh et al 2005) (figure 1). The emplacement of different granitoid plutons was controlled by pre-existing fractures and lineaments (Evans 1964; Nandy 1980). The occurrences of discordant mafic xenoliths within these plutons suggest their undoubted magmatic origin. But in some cases, the presence of sedimentary/metasedimentary xenoliths within the granitoid plutons is truly significant, recording a strong sedimentary influence in the course of their evolution. The current investigation at and around Mylliem $\left(25^{\circ} 26^{\prime} \mathrm{N}\right.$ to $25^{\circ} 32^{\prime} \mathrm{N}$ and $91^{\circ} 49^{\prime} \mathrm{E}$ to $91^{\circ} 52^{\prime} \mathrm{E}$ ), East Khasi Hills district, Meghalaya brings out the occurrence of granitoid pluton intrusive into the Shillong Group of rocks. Currently, only a rudimentary idea on the petrochemistry of the Mylliem granitoids is available (Rahman 1985). This paper, for the first time, highlights the field occurrence, petrography and geochemistry of granitoid pluton at and around Mylliem $\left(25^{\circ} 26^{\prime} \mathrm{N}\right.$ to $25^{\circ} 32^{\prime} \mathrm{N}$ and $91^{\circ} 49^{\prime} \mathrm{E}$ to $91^{\circ} 52^{\prime} \mathrm{E}$ ), East Khasi Hills, Meghalaya in order to build up a cogent petrogenetic model and to place constraints on tectonic evolution of the Mylliem pluton.

\section{Geological setting}

The Meghalaya Plateau forms a part of the northeastern extension of the Indian Peninsular Shield (Gupta and Sen 1988). It is an E-W trending, oblong, uplifted horst-block elevated about 600$1800 \mathrm{~m}$ above the Bangladesh Plains in the south. The uparching of the landmass forming a horst has been facilitated by extensive faulting (Srivastava

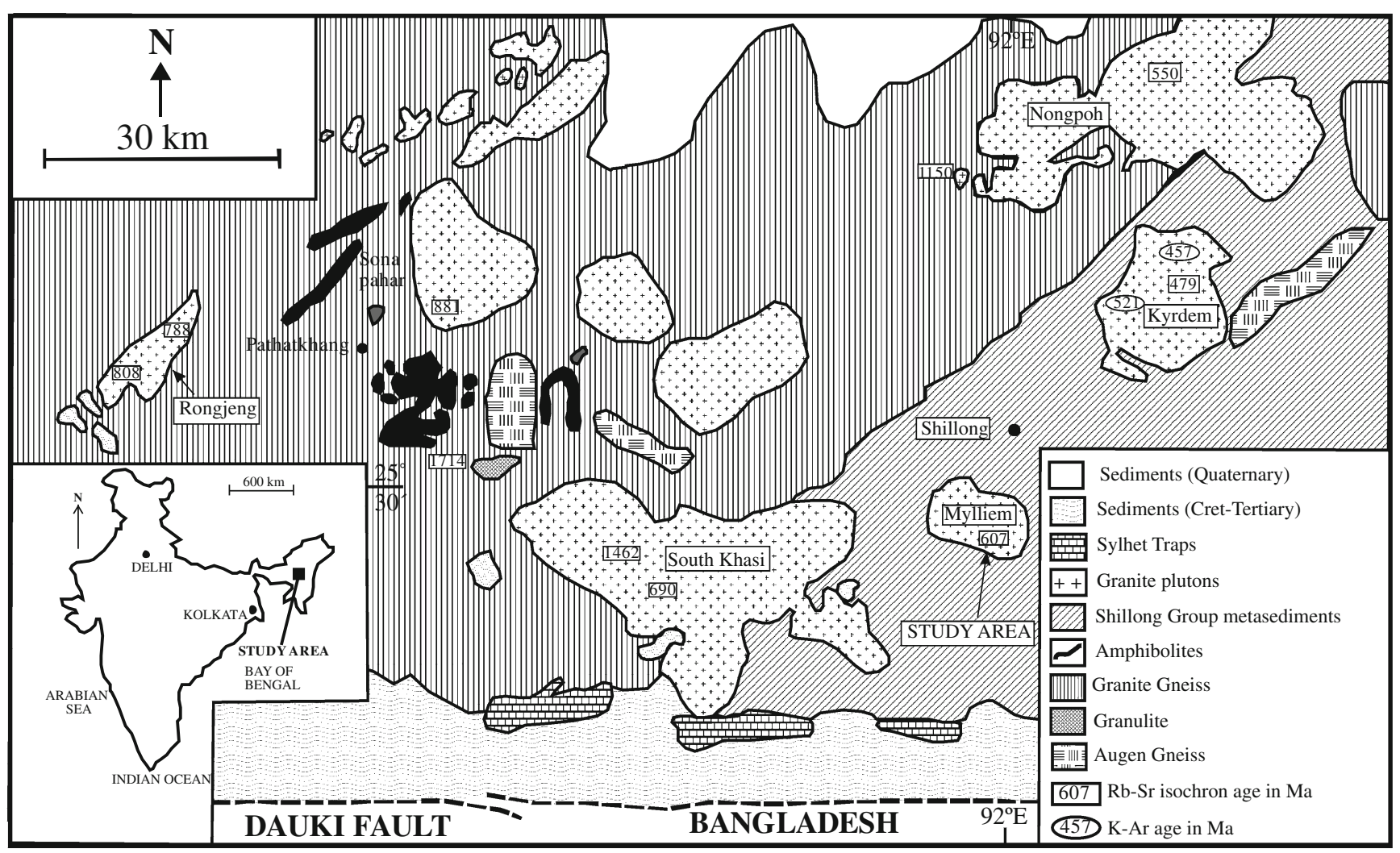

Figure 1. Geological map of Meghalaya showing the granitoid plutons with isotopic ages (after Ghosh et al 2005). Inset map shows the position of study area in the map of India. 
and Sinha 2004). The Meghalaya Plateau covers an area of about $4 \times 10^{4} \mathrm{~km}^{2}$ and is bounded by the $\mathrm{E}-\mathrm{W}$ trending Brahmaputra fault systems in the north and the Dauki fault systems in the south (Nandy 2001). The western and the eastern sides are bordered by the $\mathrm{N}-\mathrm{S}$ trending Jamuna fault system and the NW-SE trending Kopili fracture zone, the latter separating the Meghalaya Plateau from the Mikir Hills (Evans 1964; Desikachar 1974; Acharyya et al 1986; Nandy 1986; Gupta and Sen 1988; Nandy 2001).

The geology of the Meghalaya Plateau has been dealt with by several workers (Desikachar 1974; Mazumdar 1976; Das Gupta and Biswas 2000). The lithostratigraphic succession of the
Meghalaya Plateau suggested by Mazumdar (1976) is presented below:

Mesozoic-Tertiary sedimentary rocks Unconformity-

Sylhet Traps of pre-Upper Cretaceous age Fault contact-

Porphyritic granite

-Intrusive contact-

Khasi Greenstone Belt

Shillong Group

Unconformity-

Non-porphyritic migmatitic granitoid

Diffused contact-

Archaean basement gneissic complex

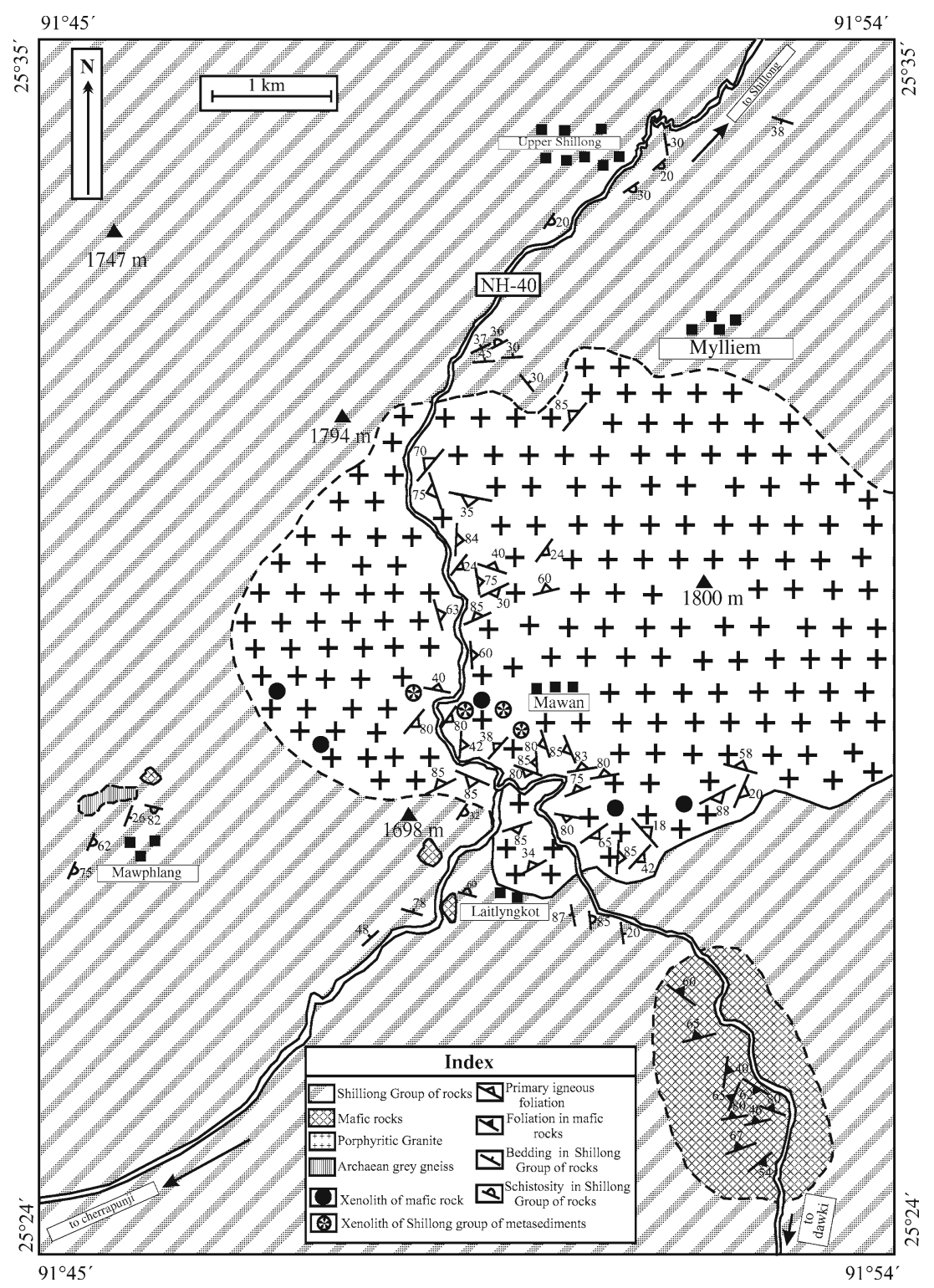

Figure 2. Geological map of the study area prepared by the first and second authors. For granitoid, only representative attitudes of primary igneous foliation have been shown. 
The Archaean basement gneissic complex consists of two different units viz., gneissic complex proper and the non-porphyritic migmatitic granitoid rocks (Mazumdar 1976; Nandy 2001). The gneissic complex proper is made up of an assortment of rock types including sillimanite-bearing gneisses, amphibolite, granulites, granite gneisses, etc. The Shillong Group of rocks were deposited in a 240-km long, NE-SW trending intracratonic basin resting unconformably, as indicated by a basal conglomerate, over the basement gneissic complex (Nandy 2001). The Shillong Group of rocks was later metamorphosed to Greenschist facies (Nandy 2001). These have been later intruded by concordant and discordant bodies of mafic igneous rocks referred to as Khasi Greenstones (Mazumdar 1976). Porphyritic granitoids occur as discordant plutons cutting across the Shillong Group of metasediments (e.g., Kyrdem, Mylliem plutons) and basement gneisses (Rongjeng, Sindhuli plutons). In some cases, as for example in Nongpoh and South Khasi areas, the granitoid plutons intrude both the Shillong Group and the gneissic complex (Ghosh et al 2005). The Cretaceous Sylhet Trap basalts and Tertiary shelf sediments occupy the southern fringe of the plateau (figure 1).

\section{Mode of occurrence}

The currently investigated Mylliem pluton has been the earliest described pluton from the Meghalaya Plateau and is named after a village of the same name located near Shillong (Nandy 2001). The Mylliem pluton covers an area of about $40 \mathrm{~km}^{2}$ and is intrusive into the metasedimentary and quartzitic rocks of the Shillong Group (figure 2). Current field studies indicate that the pluton is exposed in a roughly elliptical outcrop, the longer axis being approximately $\mathrm{E}-\mathrm{W}$ and $8.4 \mathrm{~km}$ in length, the $\mathrm{E}-\mathrm{W}$ elongation is oblique to the prevailing NE-SW strike of the enclosing Shillong Group of rocks. Mylliem granitoids are structurally characterized by primary foliations developed mainly along the margin of the pluton. The primary foliation is defined by the preferential parallel alignment of lath-shaped prismatic megacrysts of feldspar (around $4 \mathrm{~cm}$ in length) embedded in a more or less equigranular groundmass mainly composed of quartz, biotite, muscovite and feldspar. In some exposures, the primary foliation exhibits a swerving attitude due to variation in the orientation of lath-shaped feldspar megacrysts. The intrusive nature of the magma giving rise to Mylliem granitoids can be conjectured from field evidences such as (a) local apophyses and tongues of Mylliem granitoid extending into the Shillong Group of rocks and (b) occurrence of discrete xenoliths

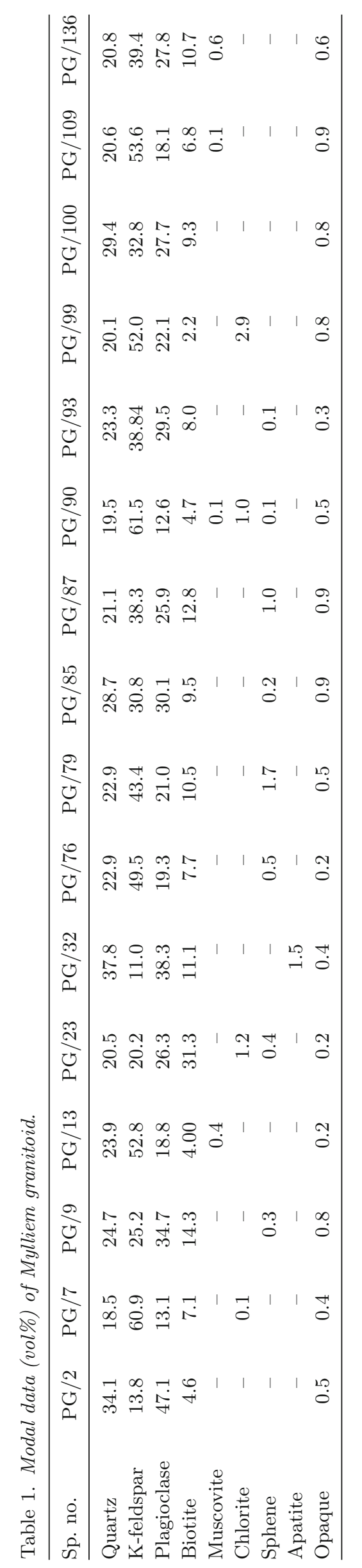


of Shillong Group of metasediments and metabasic rocks within Mylliem granitoids. Detailed structural studies in the study area reveal that the dip of primary foliation is towards the central portion of the pluton and roughly parallel to the trend of the margin indicating a funnel-shaped intrusion. The attitudes of primary foliation planes of Mylliem granitoids have been projected in a stereo pole diagram where the poles to the primary foliation are found to be distributed along a small circle girdle with a sub-vertical girdle axis $\left(\sim 70^{\circ}\right)$. Such a distribution pattern of primary foliation is suggestive of forceful injection from the parent magma. Field-relations clearly indicate that the Mylliem pluton forms a domal up-arch (figure 2) within the surrounding Shillong Group of rocks. This would imply a domal intrusion of Mylliem granitoid into the Shillong Group of rocks. There is no evidence of shearing in Mylliem granitoids and reduction of grain size of the megacrysts at the place of contact.

\section{Petrography}

Mylliem granitoids are distinctly characterized by the development of pink to white coloured phenocrysts (length ranging up to $4 \mathrm{~cm}$ ) of feldspar. Microscopic studies reveal that the phenocrysts are mainly composed of prismatic grains of microcline and lath-shaped plagioclase. Perthite occurs in both flame and string varieties showing welldeveloped exsolution lamellae. Anorthite content of plagioclase varies from $\mathrm{An}_{20}$ to $\mathrm{An}_{29}$ (determined by $\mathrm{X}^{\prime \wedge} 010$ symmetric extinction angle) corresponding to oligoclase. Groundmass composition is characterized by the presence of quartz, microcline, plagioclase, muscovite and biotite. Muscovite occurs in two forms. One type is flaky muscovite with idiomorphic outlines closely associated with biotite, while another type occurs as irregular tiny flakes within altered plagioclase. Accessory minerals include opaque grains formed at the expense of biotite and sphene, lozenge-shaped grains of apatite and sphene. Large phenocrysts of microcline and plagioclase are embedded in a groundmass of quartz, feldspar and mica representing porphyritic texture. In some places, vermicular intergrowth of quartz within plagioclase is observed depicting myrmekitic texture. Graphic texture is also present. Saussuritization of plagioclase is a common feature. Modal analyses of representative samples from Mylliem pluton has been presented in table 1. According to the IUGS system of classification, the Mylliem granitoids, on the basis of their modal mineralogy, occupy the fields of granite and granodiorite in the $\mathrm{Q}-\mathrm{A}-\mathrm{P}$ diagram of Streckeisen (1976) (figure 3).

\section{Geochemistry}

\subsection{Sampling and analytical techniques}

Systematic samplings were carried out in the study area at and around Mylliem $\left(25^{\circ} 26^{\prime} \mathrm{N}\right.$ to $25^{\circ} 32^{\prime} \mathrm{N}$ and $91^{\circ} 49^{\prime} \mathrm{E}$ to $91^{\circ} 52^{\prime} \mathrm{E}$ ) and over 65 samples were collected in order to represent the rock types from the Mylliem pluton. In all cases, efforts had been made to collect fresh samples free from alterations and any secondary minerals. Major and trace element (including REE) analyses of nine representative samples of Mylliem granitoid were carried out at the National Geophysical Research Institute, Hyderabad. The major oxides were analysed

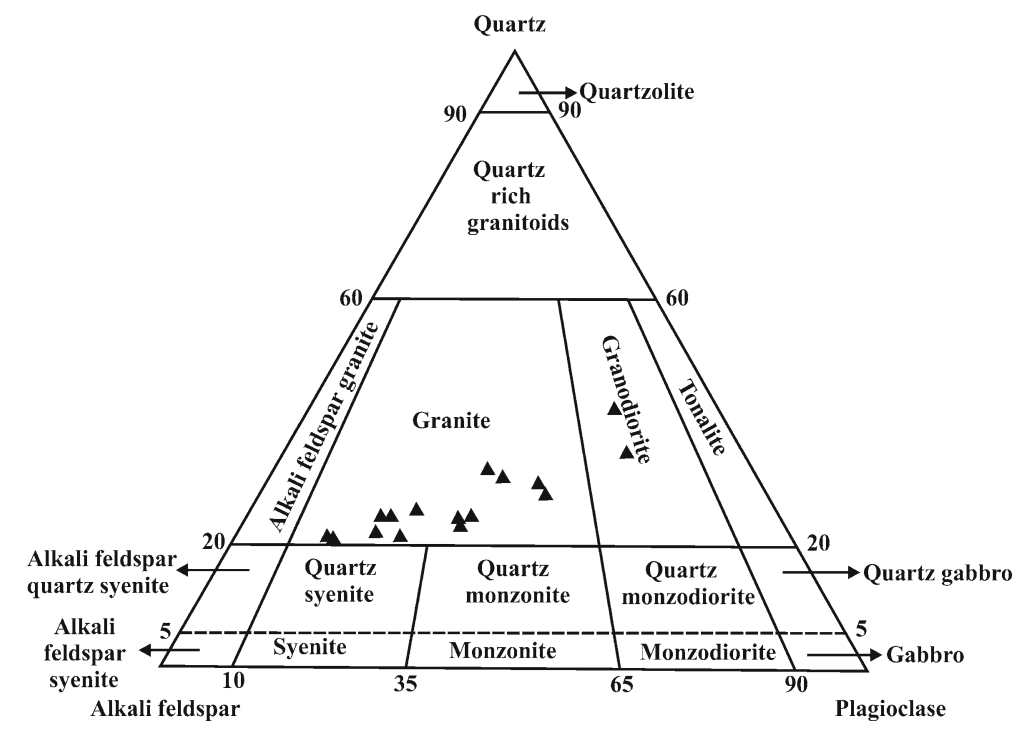

Figure 3. Modal plots of Mylliem granitoid in IUGS-recommended Q-A-P diagram (Streckeisen 1976). 
Table 2. Major oxide data (wt.\%) of Mylliem granitoid.

\begin{tabular}{|c|c|c|c|c|c|c|c|c|c|}
\hline Sp. no. & $\mathrm{PG} / 2$ & $\mathrm{PG} / 23$ & PG/79 & PG/85 & $\mathrm{PG} / 87$ & PG/93 & PG/99 & PG/100 & PG/136 \\
\hline $\mathrm{SiO}_{2}$ & 68.86 & 62.13 & 68.11 & 72.12 & 68.85 & 69.41 & 71.9 & 71.37 & 72.08 \\
\hline $\mathrm{TiO}_{2}$ & 0.56 & 1.25 & 0.52 & 0.62 & 0.46 & 0.53 & 0.49 & 0.47 & 0.56 \\
\hline $\mathrm{Al}_{2} \mathrm{O}_{3}$ & 16.11 & 16.16 & 14.28 & 13.5 & 14.48 & 14.07 & 12.58 & 14.7 & 13.76 \\
\hline $\mathrm{Fe}_{2} \mathrm{O}_{3}$ & 3.65 & 6.42 & 3.43 & 3.82 & 3.02 & 3.4 & 3.31 & 3.22 & 3.97 \\
\hline $\mathrm{MnO}$ & 0.08 & 0.09 & 0.06 & 0.08 & 0.06 & 0.07 & 0.07 & 0.07 & 0.09 \\
\hline $\mathrm{MgO}$ & 1.12 & 2.15 & 1.2 & 1.11 & 1.07 & 1.05 & 1 & 0.82 & 1.05 \\
\hline $\mathrm{CaO}$ & 1 & 2.36 & 2.06 & 1.45 & 2 & 2.51 & 1.91 & 0.45 & 0.84 \\
\hline $\mathrm{Na}_{2} \mathrm{O}$ & 2.16 & 1.73 & 2.5 & 2.13 & 2.83 & 3.04 & 2.59 & 3.11 & 1.77 \\
\hline $\mathrm{K}_{2} \mathrm{O}$ & 4.48 & 5.17 & 5.65 & 3.78 & 5.19 & 4.11 & 4.01 & 4.57 & 4.54 \\
\hline $\mathrm{P}_{2} \mathrm{O}_{5}$ & 0.28 & 0.66 & 0.24 & 0.25 & 0.19 & 0.22 & 0.21 & 0.19 & 0.16 \\
\hline LOI & 1.13 & 0.98 & 0.18 & 1.18 & 0.22 & 0.84 & 1.22 & 0.46 & 1.42 \\
\hline Total & 99.43 & 99.1 & 98.23 & 100.04 & 98.37 & 99.25 & 99.29 & 99.43 & 100.24 \\
\hline $\mathrm{Na}_{2} \mathrm{O}+\mathrm{K}_{2} \mathrm{O}$ & 6.64 & 6.9 & 8.15 & 5.91 & 8.02 & 7.15 & 6.6 & 7.68 & 6.31 \\
\hline $\mathrm{A} / \mathrm{CNK}$ & 2.11 & 1.75 & 1.4 & 1.83 & 1.45 & 1.46 & 1.48 & 1.81 & 1.92 \\
\hline $\mathrm{A} / \mathrm{NK}$ & 2.43 & 2.34 & 1.75 & 2.28 & 1.81 & 1.97 & 1.91 & 1.91 & 2.18 \\
\hline $\mathrm{K}_{2} \mathrm{O} / \mathrm{Na}_{2} \mathrm{O}$ & 2.07 & 2.99 & 2.26 & 1.77 & 1.83 & 1.35 & 1.55 & 1.47 & 2.56 \\
\hline $\mathrm{Ti} / \mathrm{P}$ & 2.75 & 2.6 & 2.97 & 3.41 & 3.32 & 3.31 & 3.2 & 3.4 & 4.81 \\
\hline *A.S.I. & 1.5 & 1.3 & 1 & 1.3 & 1 & 1 & 1 & 1.2 & 1.3 \\
\hline${ }^{\#} \mathrm{Fe}^{*}$ & 0.74 & 0.73 & 0.72 & 0.75 & 0.72 & 0.74 & 0.75 & 0.78 & 0.77 \\
\hline$\#^{\#}$ MALI & 5.64 & 4.54 & 6.09 & 4.46 & 6.02 & 4.64 & 4.69 & 7.23 & 5.47 \\
\hline \multicolumn{10}{|l|}{ CIPW norm } \\
\hline Quartz & 36.75 & 26.37 & 26.94 & 41.68 & 27.69 & 30.15 & 37.21 & 34.49 & 41.99 \\
\hline Corundum & 6.67 & 5.09 & 0.89 & 3.91 & 1.04 & 0.59 & 1.02 & 4.31 & 4.84 \\
\hline Orthoclase & 26.93 & 31.14 & 34.05 & 22.59 & 31.25 & 24.68 & 24.16 & 27.29 & 27.15 \\
\hline Albite & 18.59 & 14.92 & 21.57 & 18.23 & 24.4 & 26.14 & 22.35 & 26.59 & 15.16 \\
\hline Anorthite & 3.19 & 7.54 & 8.83 & 5.63 & 8.85 & 11.19 & 8.26 & 1 & 3.16 \\
\hline Hypersthene & 2.83 & 5.43 & 3.04 & 2.78 & 2.7 & 2.65 & 2.53 & 2.05 & 2.64 \\
\hline Magnetite & 0.26 & 0.3 & 0.2 & 0.26 & 0.2 & 0.23 & 0.23 & 0.23 & 0.29 \\
\hline Haematite & 3.53 & 6.34 & 3.36 & 3.68 & 2.94 & 3.3 & 3.22 & 3.1 & 3.81 \\
\hline Rutile & 0.47 & 1.15 & 0.45 & 0.53 & 0.39 & 0.45 & 0.41 & 0.39 & 0.46 \\
\hline Apatite & 0.62 & 1.47 & 0.53 & 0.55 & 0.42 & 0.49 & 0.47 & 0.42 & 0.35 \\
\hline$* *$ D.I. & 82.27 & 72.43 & 82.57 & 82.5 & 83.33 & 80.97 & 83.72 & 88.37 & 84.29 \\
\hline
\end{tabular}

*A.S.I: Alumina saturation index; ${ }^{* *}$ D.I.: Diffentiation index; ${ }^{\#} \mathrm{Fe}^{*}$ : $\mathrm{FeO}^{(t)} /\left(\mathrm{FeO}^{(t)}+\mathrm{MgO}\right)$; \#\# MALI: Modified alkali lime index.

by XRF while the trace elements (including REE) were analysed by ICP-MS. The procedures and accuracy and precision of XRF method adopted during this study have been proposed by Acharyya et al (2006), while the analytical details and precision involved in ICP-MS have been given by Satyanarayanan et al (2006). The whole rock major (wt.\% oxides) and trace element (including REE) (ppm) data for the Mylliem granitoids have been furnished in tables 2 and 3.

\subsection{Major and trace element characteristics}

Major oxide data (table 2) reveal that the Mylliem granitoids have a variable composition with moderate-to-high silica $\left(\mathrm{SiO}_{2}\right.$ ranging from 62.13 to 72.12 wt.\%) and low content of $\mathrm{CaO}(0.45$ to 2.51 wt. \%), $\mathrm{MgO}$ (0.82 to 2.15 wt.\%), $\mathrm{TiO}_{2}(0.46$ to 1.25 wt. $\%$ ), $\mathrm{MnO}$ (0.06 to 0.09 wt.\%) and $\mathrm{P}_{2} \mathrm{O}_{5}$ (0.16 to 0.66 wt.\%). Total alkali content ranges from 5.19 to 8.15 wt. $\%$, while $\mathrm{Al}_{2} \mathrm{O}_{3}$ ranges from 12.58 to 16.16 wt. $\% . \mathrm{K}_{2} \mathrm{O}$ varies between 3.78 and 5.65 wt. $\%$ and is higher than $\mathrm{Na}_{2} \mathrm{O}$, which ranges from 1.73 to 3.11 wt.\%. $\mathrm{K}_{2} \mathrm{O} / \mathrm{Na}_{2} \mathrm{O}$ ratio ranges from 1.35 to 2.99 depicting the potash-rich character of Mylliem granitoids. CIPW normative compositions have been calculated on an anhydrous basis for the analysed Mylliem granitoid samples (table 2). The Mylliem granitoid samples fall within the field of 'Granite' in the normative $\mathrm{An}-\mathrm{Ab}-$ Or diagram (after O'Connor 1965). Compositional plots of Mylliem granitoids in the $\mathrm{CaO}-\mathrm{Na}_{2} \mathrm{O}-$ $\mathrm{K}_{2} \mathrm{O}$ ternary diagram (after Barker and Arth 1976) indicate that the data-points occupy the field of 'Granite' with a minor spill to the field of 'Quartz Monzonite'. 
Table 3. Trace element (including rare earth element) data (in ppm) of Mylliem granitoid.

\begin{tabular}{|c|c|c|c|c|c|c|c|c|c|}
\hline Sp. no. & $\mathrm{PG} / 2$ & $\mathrm{PG} / 23$ & $\mathrm{PG} / 79$ & $\mathrm{PG} / 85$ & $\mathrm{PG} / 87$ & PG/93 & PG/99 & $\mathrm{PG} / 100$ & PG/136 \\
\hline $\mathrm{Sc}$ & 5.77 & 7.63 & 7.88 & 7.8 & 6.18 & 6.44 & 6.89 & 8.07 & 7.74 \\
\hline $\mathrm{V}$ & 1.27 & 1.6 & 1.64 & 1.17 & 1.04 & 1.1 & 1.64 & 0.96 & 1.53 \\
\hline $\mathrm{Cr}$ & 10.31 & 7.63 & 6.46 & 8.14 & 7.71 & 7.6 & 10.12 & 7.9 & 7.58 \\
\hline $\mathrm{Co}$ & 54.6 & 36.1 & 141.04 & 143.77 & 110.31 & 152.06 & 86.35 & 106.24 & 66.61 \\
\hline $\mathrm{Ni}$ & 3.71 & 2.5 & 2.58 & 2.9 & 2.66 & 2.62 & 2.35 & 2.46 & 2.84 \\
\hline $\mathrm{Cu}$ & 0.65 & 0.74 & 0.78 & 0.74 & 0.68 & 0.81 & 0.61 & 0.99 & 0.69 \\
\hline $\mathrm{Zn}$ & 18.65 & 27.78 & 28.81 & 23.01 & 22.78 & 29.83 & 25.32 & 25.85 & 27.26 \\
\hline $\mathrm{Ga}$ & 14.48 & 12.24 & 19.92 & 16.8 & 16.81 & 16.96 & 16.53 & 20.35 & 13.59 \\
\hline $\mathrm{Rb}$ & 226.61 & 140.76 & 300.08 & 284.98 & 294.61 & 237.31 & 233.63 & 365.12 & 236.83 \\
\hline $\mathrm{Sr}$ & 74.91 & 141.62 & 245.3 & 139.86 & 182.86 & 189.7 & 155.15 & 87.04 & 73.9 \\
\hline $\mathrm{Y}$ & 34.43 & 35.41 & 83.76 & 45.85 & 52.38 & 55.87 & 42.65 & 56.16 & 43.54 \\
\hline $\mathrm{Zr}$ & 156.24 & 284.47 & 236.35 & 296.97 & 243.06 & 243.36 & 262.15 & 225.67 & 193.63 \\
\hline $\mathrm{Nb}$ & 27.69 & 24.01 & 39.2 & 35.21 & 28.23 & 25.44 & 33.27 & 41.05 & 29.3 \\
\hline Cs & 8.58 & 4.7 & 8.86 & 13.19 & 8.91 & 5.55 & 5.12 & 9.76 & 9.95 \\
\hline $\mathrm{Ba}$ & 153.81 & 257.43 & 336.83 & 200.28 & 280.41 & 223.59 & 144.67 & 221.59 & 120.24 \\
\hline Hf & 5.32 & 7.1 & 7.37 & 9.39 & 7.37 & 7.5 & 8.48 & 7.64 & 6.43 \\
\hline $\mathrm{Ta}$ & 1.54 & 1.8 & 5.32 & 4.38 & 2.51 & 1.89 & 2.44 & 4.25 & 3.41 \\
\hline $\mathrm{Pb}$ & 43.42 & 32.91 & 47.73 & 46.45 & 50.35 & 68.43 & 65.67 & 43.89 & 39.05 \\
\hline $\mathrm{Th}$ & 49.9 & 32.52 & 70.41 & 74.79 & 58.21 & 57.17 & 66.64 & 85.39 & 51.1 \\
\hline $\mathrm{U}$ & 15.38 & 4.8 & 11.92 & 21.33 & 14.98 & 11.55 & 20.71 & 15.98 & 14.11 \\
\hline $\mathrm{Rb} / \mathrm{Sr}$ & 3.02 & 0.99 & 1.22 & 2.04 & 1.61 & 1.25 & 1.51 & 4.19 & 3.2 \\
\hline $\mathrm{Ba} / \mathrm{Rb}$ & 0.68 & 1.83 & 1.12 & 0.7 & 0.95 & 0.94 & 0.62 & 0.61 & 0.51 \\
\hline $\mathrm{Ba} / \mathrm{Sr}$ & 2.05 & 1.82 & 1.37 & 1.43 & 1.53 & 1.18 & 0.93 & 2.55 & 1.63 \\
\hline $\mathrm{Th} / \mathrm{U}$ & 3.24 & 6.77 & 5.91 & 3.51 & 3.89 & 4.95 & 3.22 & 5.34 & 3.62 \\
\hline $\mathrm{K} / \mathrm{Rb}$ & 164.09 & 304.86 & 156.27 & 110.09 & 146.22 & 143.75 & 142.46 & 103.89 & 159.11 \\
\hline $\mathrm{K} / \mathrm{Ba}$ & 241.76 & 166.69 & 139.22 & 156.65 & 153.62 & 152.57 & 230.06 & 171.17 & 313.4 \\
\hline $\mathrm{La}$ & 40.17 & 92.98 & 40.62 & 83.7 & 65.66 & 76.94 & 66.32 & 89.75 & 28.5 \\
\hline $\mathrm{Ce}$ & 96.79 & 130.17 & 80.68 & 130.29 & 129.06 & 152.15 & 131.26 & 192.08 & 101.5 \\
\hline $\operatorname{Pr}$ & 8.5 & 19.47 & 8.14 & 19.54 & 13.52 & 15.58 & 13.66 & 17.61 & 6.02 \\
\hline $\mathrm{Nd}$ & 32.25 & 73.6 & 30.36 & 73.27 & 50.96 & 58.39 & 50.78 & 63.07 & 23.95 \\
\hline $\mathrm{Sm}$ & 6.33 & 11.53 & 5.5 & 12.74 & 9.41 & 10.77 & 9.01 & 10.87 & 5.63 \\
\hline $\mathrm{Eu}$ & 0.55 & 1.16 & 0.6 & 1 & 0.95 & 0.92 & 0.68 & 0.83 & 0.52 \\
\hline Gd & 6.45 & 11.76 & 5.85 & 12.57 & 9.85 & 10.96 & 9.62 & 12.06 & 6.16 \\
\hline $\mathrm{Tb}$ & 0.94 & 1.34 & 0.77 & 1.5 & 1.37 & 1.51 & 1.23 & 1.49 & 1.03 \\
\hline Dy & 6.1 & 6.81 & 4.66 & 8.36 & 8.53 & 9.41 & 7.07 & 8.65 & 7.54 \\
\hline Ho & 0.7 & 0.73 & 0.52 & 0.93 & 0.94 & 1.06 & 0.8 & 0.95 & 0.85 \\
\hline Er & 2.5 & 2.56 & 1.86 & 3.37 & 3.44 & 3.72 & 2.73 & 3.53 & 2.86 \\
\hline $\mathrm{Tm}$ & 0.35 & 0.28 & 0.25 & 0.43 & 0.45 & 0.48 & 0.32 & 0.42 & 0.39 \\
\hline $\mathrm{Yb}$ & 3.88 & 2.94 & 2.95 & 4.99 & 4.87 & 5.06 & 3.54 & 4.36 & 4.16 \\
\hline $\mathrm{Lu}$ & 0.65 & 0.46 & 0.47 & 0.82 & 0.8 & 0.81 & 0.61 & 0.72 & 0.63 \\
\hline ¿REE & 206.14 & 355.79 & 183.21 & 353.5 & 299.81 & 347.76 & 297.63 & 406.37 & 189.73 \\
\hline$(\mathrm{Ce} / \mathrm{Yb})_{N}$ & 1.4 & 1.65 & 1.44 & 1.42 & 1.42 & 1.48 & 1.57 & 1.64 & 1.39 \\
\hline$(\mathrm{Ho} / \mathrm{Yb})_{N}$ & 0.54 & 0.75 & 0.53 & 0.56 & 0.58 & 0.63 & 0.68 & 0.66 & 0.61 \\
\hline$(\mathrm{La} / \mathrm{Yb})_{N}$ & 1.02 & 1.5 & 1.14 & 1.22 & 1.13 & 1.18 & 1.27 & 1.31 & 0.84 \\
\hline $\mathrm{Eu} / \mathrm{Eu}^{*}$ & 0.16 & 0.3 & 0.32 & 0.24 & 0.3 & 0.42 & 0.22 & 0.21 & 0.25 \\
\hline
\end{tabular}

In the Harker variation diagrams (figure 4), $\mathrm{Al}_{2} \mathrm{O}_{3}, \mathrm{TiO}_{2}, \mathrm{MgO}$ and $\mathrm{P}_{2} \mathrm{O}_{5}$ show a systematic decrease with increasing $\mathrm{SiO}_{2}$, while $\mathrm{FeO}^{t} / \mathrm{MgO}$ and $\mathrm{Ti} / \mathrm{P}$ show a systematic increase with rising $\mathrm{SiO}_{2}$. Among trace elements, $\mathrm{Rb}, \mathrm{Nb}, \mathrm{K} / \mathrm{Ba}$ and $\mathrm{Rb} / \mathrm{Sr}$ depict significant positive correlation with $\mathrm{SiO}_{2}$, while $\mathrm{K} / \mathrm{Rb}$ shows a negative trend. Ba and $\mathrm{Sr}$ show a prominent decreasing trend with increasing $\mathrm{SiO}_{2}$.

Trace element data (table 3) for the Mylliem granitoids depicts variable concentrations of trace elements including REE. Figure 4 indicates that $\mathrm{Sr}$ shows a gradual increase with increasing $\mathrm{Ba}$ while $\mathrm{Zr}$ depicts a positive correlation with $\mathrm{Y}$. 

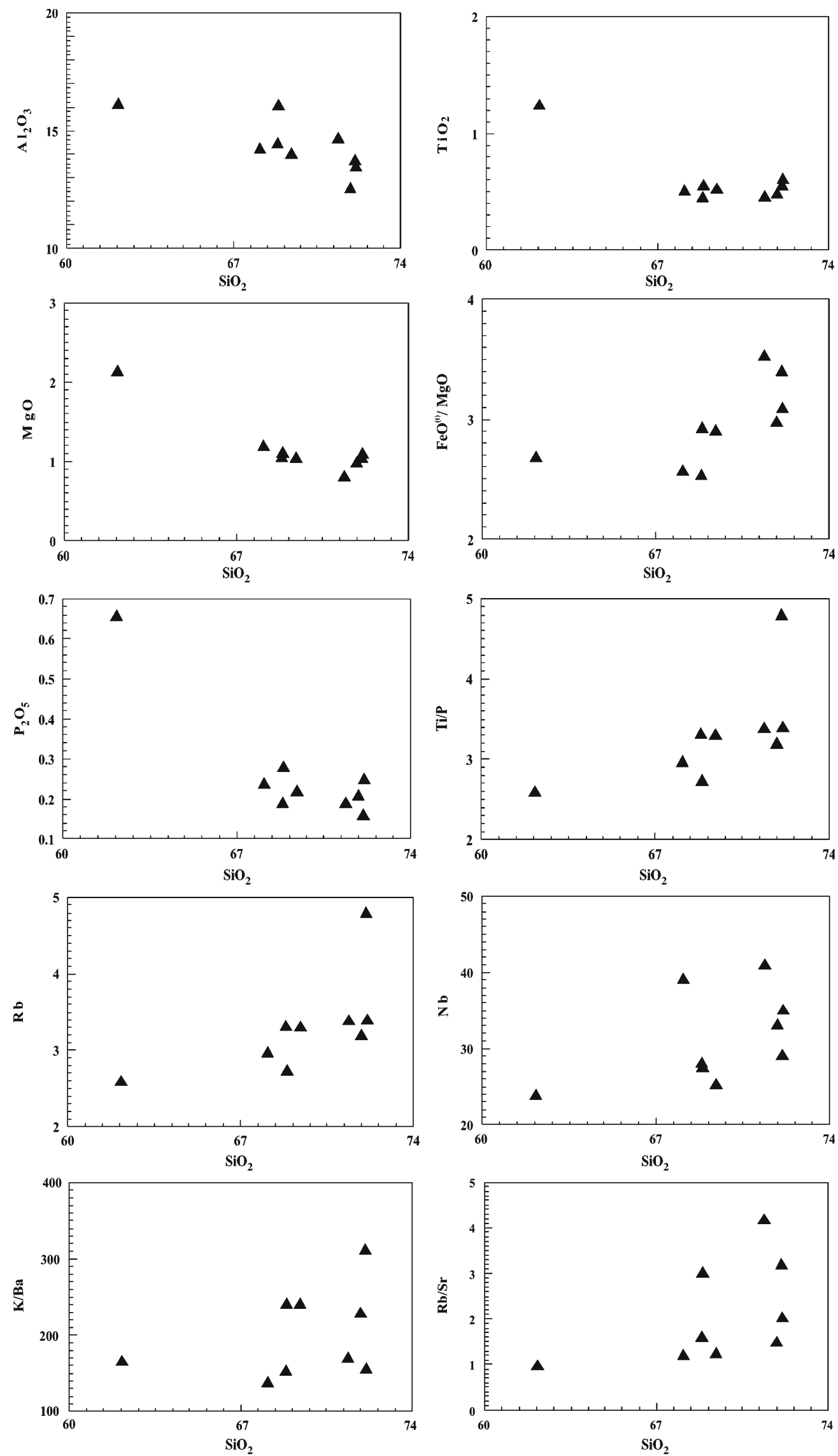

Figure 4. Harker variation diagrams for Mylliem granitoid. 

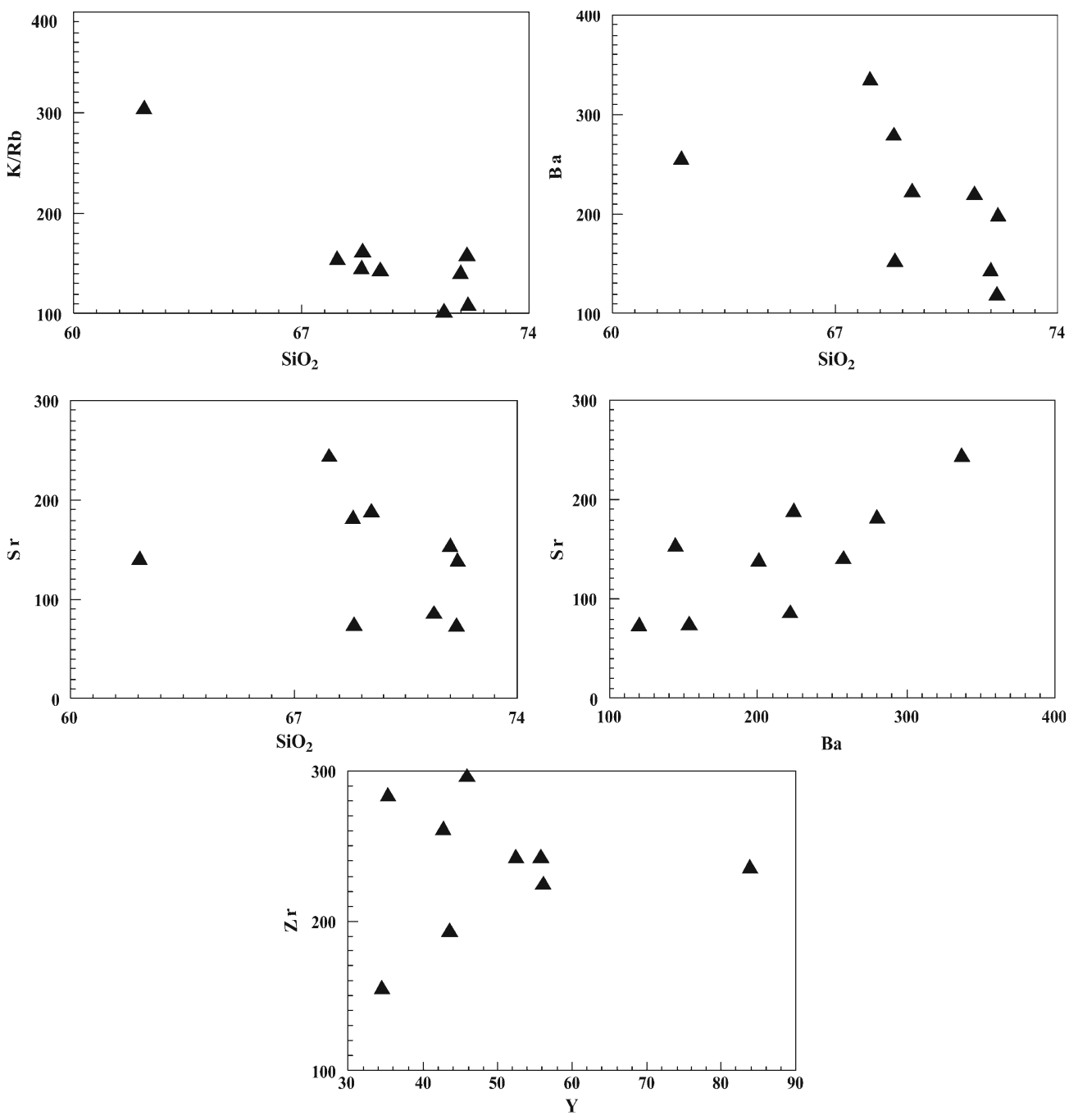

Figure 4. (Continued).

Chondrite-normalized multi-element diagram for incompatible trace element patterns of Mylliem granitoids depicts negative $\mathrm{Nb}$ and $\mathrm{Sr}$ anomalies (figure 5a). The Mylliem granitoids are characterized by high concentrations of $\mathrm{U}$ and $\mathrm{Th}$ (figure 5a), while high field strength elements such as $\mathrm{Zr}$ and $\mathrm{Y}$ show moderate abundances. The $\mathrm{U}$ content ranges from 4.8 to $21.3 \mathrm{ppm}$ which is much higher than the value of $3.5-5 \mathrm{ppm}$ usually present in normal granites (Krauskopf 1982; Singh 2007). Thorium content ranges from 32.52 to $85.39 \mathrm{ppm}$. Thus, the currently investigated granitoids are characterized by distinct uranium and thorium enrichment (Sen et al 2009). Critical examination of $\mathrm{Th} / \mathrm{U}$ ratios (ranging from 3.22 to 6.77 ) indicates a relatively higher abundance of thorium over uranium and thereby suggests significant thorium mineralization in the Mylliem pluton. The chondrite-normalized REE patterns (Sun and Mc Donough 1989) of the Mylliem granitoids are depicted in figure 5(b). The granitoids are enriched in LREE and show prominent negative
Eu anomaly (Eu/Eu* ranging 0.16-0.42) indicating a significant role of plagioclase fractionation from the parent magma. $(\mathrm{Ce} / \mathrm{Yb})_{N}$ values show a range of 1.39 to 1.65 (table 3) which indicates a strong REE fractionation. $(\mathrm{La} / \mathrm{Yb})_{N}$ values also suggest similar fractionation trends. $\mathrm{Ho} / \mathrm{Yb}$ ratios show a moderate range of variation ( 0.53 to 0.75$)$ which is suggestive of mild HREE fractionation.

\section{Characterization of Mylliem granitoids}

Geochemical parameters supplemented with distinctive petrographic criteria and field observations provide suitable attributes for characterization of granitoids and inferring the nature of source rocks. The geochemical characterization of granitoids is primarily based on three variables and these are $\mathrm{Fe}^{*}\left[\mathrm{FeO}^{(t)} /\left(\mathrm{FeO}^{(t)}+\mathrm{MgO}\right)\right]$, modified alkali-lime index (MALI) $\left(\mathrm{Na}_{2} \mathrm{O}+\mathrm{K}_{2} \mathrm{O}-\mathrm{CaO}\right)$ and the aluminium saturation index (ASI) $[\mathrm{Al} /(\mathrm{Ca}-1.67 \mathrm{P}+$ $\mathrm{Na}+\mathrm{K})$ ] (Shand 1943). The Mylliem granitoids 
(a)

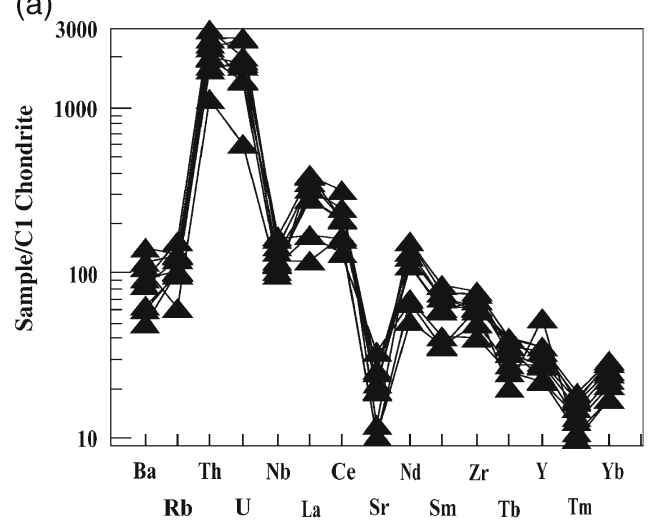

(b)

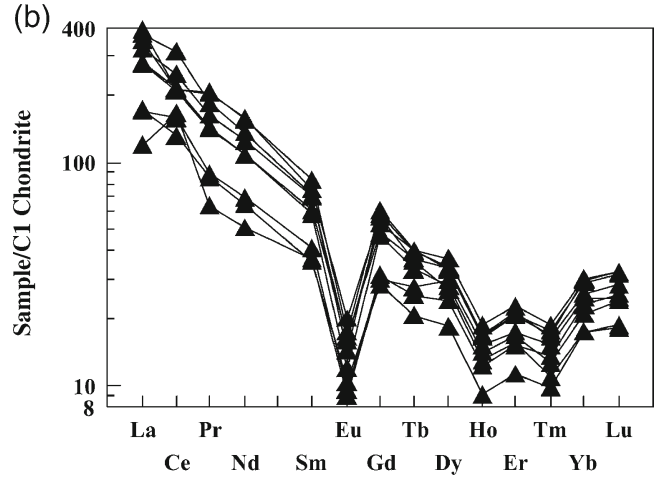

Figure 5. (a) Chondrite-normalized plot for incompatible trace elements of Mylliem granitoid. Normalization factors after Sun and McDonough (1989). (b) Chondrite-normalized rare earth element patterns of Mylliem granitoids. Normalization factors after Sun and McDonough (1989).

are characterized as magnesian granitoids with $\mathrm{Fe}^{*}$ ranging from 0.72 to 0.78 and they cluster in the 'magnesian field' of $\mathrm{FeO}^{(t)} /\left(\mathrm{FeO}^{(t)}+\mathrm{MgO}\right)$ vs. $\mathrm{SiO}_{2}$ diagram (Frost et al 2001) (figure 6a). MALI of Mylliem granitoids ranges from 4.46 to 7.23 and plots of Mylliem granitoids in $\mathrm{Na}_{2} \mathrm{O}+\mathrm{K}_{2} \mathrm{O}-\mathrm{CaO}$ vs. $\mathrm{SiO}_{2}$ diagram (Frost et al 2001) (figure 6b) depict a calc-alkalic to alkalicalcic trend thereby indicating a transitional character of Mylliem granitoids and gradual potash enrichment during the course of differentiation. The Mylliem granitoids have ASI ranging from 1.0 to 1.3 and are thus designated as peraluminous granitoids. Normative corundum (ranging between 0.59 and 6.67 wt.\%), $\mathrm{A} / \mathrm{CNK}$ ratios ranging from 1.4 to 2.11 and $\mathrm{A} / \mathrm{NK}$ ratios varying from 1.75 to 2.43 (Shand 1943; Chappell and White 1974) of the currently investigated Mylliem granitoid support its characterization as strongly peraluminous, relatively potassic, S-type granite. $\mathrm{A} / \mathrm{CNK}$ vs. $\mathrm{A} / \mathrm{NK}$ plots of Mylliem granitoids (figure 7) occupy the peraluminous field. A set of petrographic and chemical parameters for typical S-type granite, as compiled from Johannes and Holtz (1996), have been used to draw a comparison
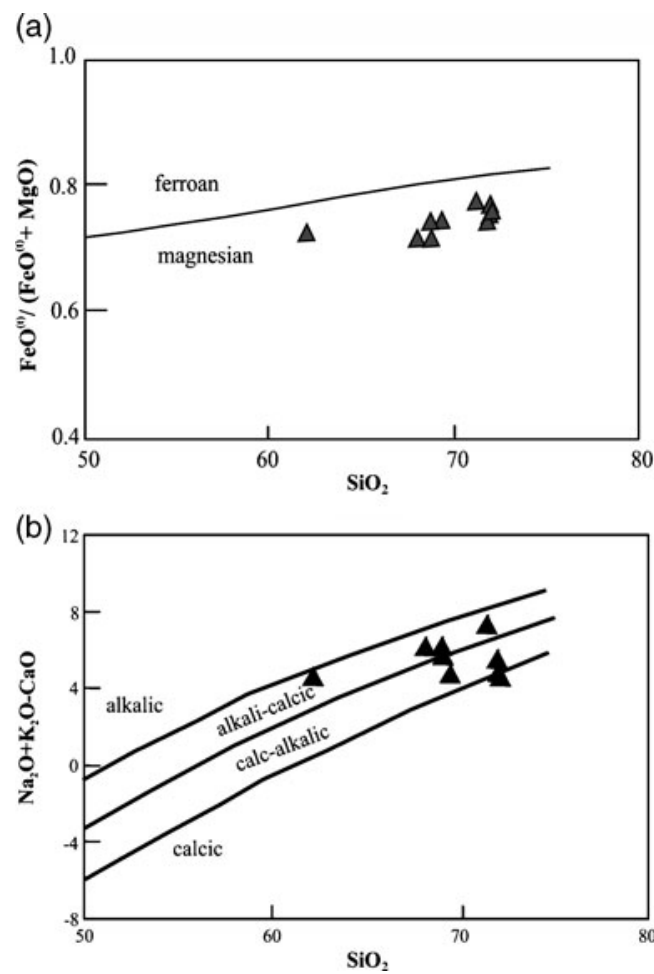

Figure 6. (a) $\mathrm{FeO}^{(t)} /\left(\mathrm{FeO}^{(t)}+\mathrm{MgO}\right)$ vs. $\mathrm{SiO}_{2}$ diagram showing the magnesian character of Mylliem granitoids (Frost et al 2001). (b) $\mathrm{Na}_{2} \mathrm{O}+\mathrm{K}_{2} \mathrm{O}-\mathrm{CaO}$ vs. $\mathrm{SiO}_{2}$ diagram depicting the calc-alkalic to alkali-calcic character of Mylliem granitoids (Frost et al 2001).

with the S-type signatures of the currently studied Mylliem granitoids.

\begin{tabular}{lll}
\hline & S-type & $\begin{array}{l}\text { Mylliem porphyritic } \\
\text { granoid }\end{array}$ \\
\hline $\mathrm{SiO}_{2}$ & $65-76 \%$ & $62.13-72.12 \%$ \\
$\mathrm{Na}_{2} \mathrm{O}$ & Low & $\begin{array}{c}\text { Low }(1.73-3.11 \\
\text { wt. } \%)\end{array}$ \\
$\mathrm{Na}_{2} \mathrm{O} / \mathrm{K}_{2} \mathrm{O}$ & Low & Low \\
$\mathrm{CIPW}$ norm & $>1 \%$ corundum & $>1 \%$ corundum \\
$\mathrm{CaO}$ & $<3.7 \%$ & $0.45-2.51 \%$ \\
$\mathrm{Cr}$ & $>45 \mathrm{ppm}$ & $6.5-10.3 \mathrm{ppm}$ \\
$\mathrm{Co}$ & $>16$ ppm & $36.1-152.1 \mathrm{ppm}$ \\
$\mathrm{Zr}$ & $>150$ ppm & $156.2-297 \mathrm{ppm}$ \\
$\mathrm{A} / \mathrm{CNK}$ & $>1.1$ & $1.4-2.1$ \\
$\mathrm{Minerals}$ & Al-silicates, & Muscovite, apatite \\
& cordierite, & \\
& muscovite, & \\
\hline
\end{tabular}

Petrographic studies of Mylliem granitoids record the presence of muscovite and individual apatite crystals which illustrate their S-type nature. Occurrence of metasedimentary xenoliths of Shillong Group within the Mylliem granitoids 


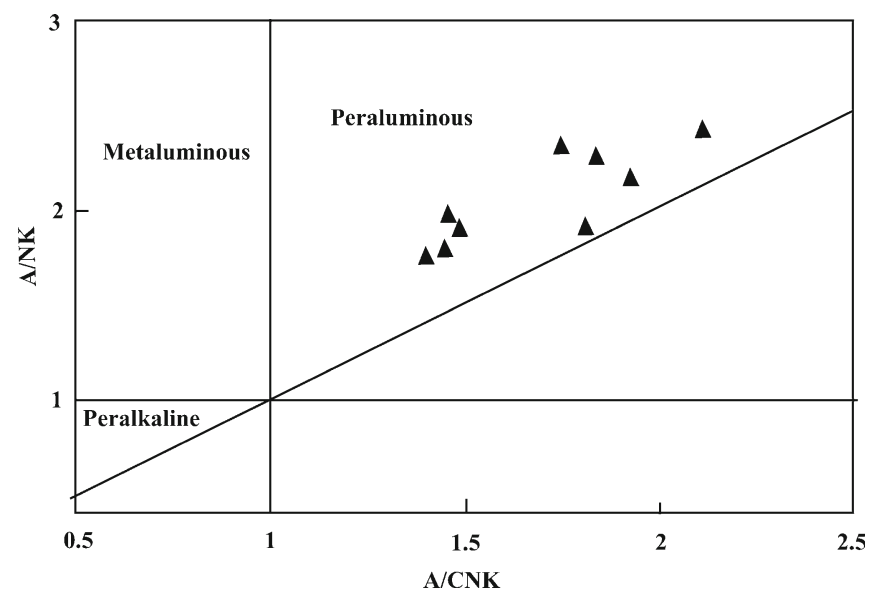

Figure 7. A/NK vs. A/CNK plots for Mylliem granitoid (after Shand 1943).

provides a distinctive field evidence for designating these granitoids as S-type granites and suggesting a sedimentary source for them (Barbarin
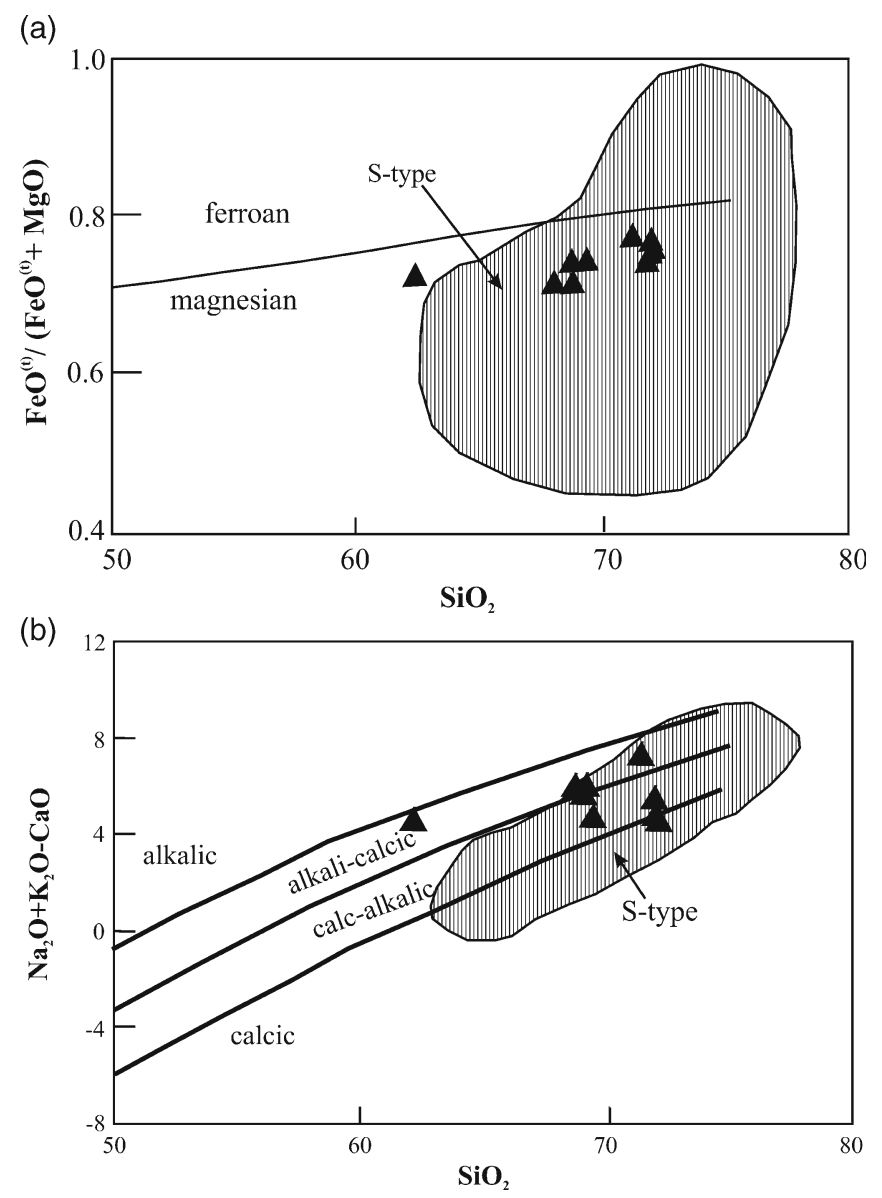

Figure 8. (a) $\mathrm{FeO}^{(t)} /\left(\mathrm{FeO}^{(t)}+\mathrm{MgO}\right)$ vs. $\mathrm{SiO}_{2}$ diagram showing the plots of Mylliem granitoids in the field of Stype granoids from Lachlan Fold Belt (Frost et al 2001). (b) $\mathrm{Na}_{2} \mathrm{O}+\mathrm{K}_{2} \mathrm{O}-\mathrm{CaO}$ vs. $\mathrm{SiO}_{2}$ diagram showing the plots of Mylliem granitoids in the field of S-type granoids from Lachlan Fold Belt (Frost et al 2001).
1999). $\mathrm{FeO}^{(t)} /\left(\mathrm{FeO}^{(t)}+\mathrm{MgO}\right)$ vs. $\mathrm{SiO}_{2}$ (figure 8a) and $\mathrm{Na}_{2} \mathrm{O}+\mathrm{K}_{2} \mathrm{O}-\mathrm{CaO}$ vs. $\mathrm{SiO}_{2}$ (figure $8 \mathrm{~b}$ ) plots of Mylliem granitoids fall in the field of S-type granitoids from the Lachlan Fold Belt. This compositional affinity suggests that the peraluminous, S-type Mylliem granitoids are chemically correlatable with the peraluminous, S-type Lachlan Fold Belt granitoids.

\section{Discussion}

Granitoids are often derived by the melting of preexisting sedimentary or meta-igneous rocks and the melt-products often give rise to generation of large- or moderate-sized batholithic intrusion in the country rock, in syn- to post-collisional tectonic environments (MacDonald 1966; Nagudi et al 2003 and references therein, Kochhar and Dhar 1993; Dhar et al 1996). In the Meghalaya Plateau (the study area), occurrences of several granite plutons have been described by Ghosh et al (2005) and significant discordant granitoid plutons have been marked as Kyrdem, Mylliem, Rongjeng, Nongpoh, South Khasi, Kyllang, etc. (figure 1). An overall syn- to late-tectonic condition was envisaged for those discordant granite plutons (Ghosh et al 2005). However, much remains unknown about the source rock characters, petrogenesis and tectonic environments of the granitoid plutons which have to be found out through sustained field investigations, petrography and geochemical studies. We now try to integrate the lithological and petrological attributes of the currently investigated Mylliem pluton on the basis of available geochemical data.

\subsection{Implications on source rock characters}

Field evidences record the occurrence of xenoliths of both Shillong Group metasediments and metabasic rocks within Mylliem granitoids. These xenolith-lithologies offer suitable clues to ascertain the source-characters of Mylliem granitoids. A question thus arises whether mafic rocks or Shillong Group of rocks should be taken as the potential source that could have given rise to Mylliem granitoids on different degrees of melting. Geochemical compositions of granitic magmas reflect the compositions of their source rocks. Certain geochemical parameters such as $\mathrm{Fe}^{*}\left[\mathrm{FeO}^{(t)} /\right.$ $\left.\left(\mathrm{FeO}^{(t)}+\mathrm{MgO}\right)\right]$, aluminium saturation index (ASI), etc., are sensitive indicators of the source regions of granitic magmas and provide reliable means for better understanding of their origin and evolution (Frost et al 2001). The differentiation paths followed by granitic magmas strongly affect the $\mathrm{Fe}^{*}$ and in this case, the magnesian character of 
the Mylliem granitoids suggest their derivation from a melt which has followed a relatively oxidizing differentiation trend. Geochemical aspects including high values of $\mathrm{Zr}$ (156-297 ppm), Co (36-152 ppm), lesser $\mathrm{CaO}$ wt.\% (0.45-2.51) and moderate $\mathrm{SiO}_{2}(\sim 62-72$ wt.\%), aided by distinct petrographic characters corroborate the peraluminous, S-type nature of the Mylliem granitoids. The ASI of granitic rocks is predominantly a function of the composition of the source rock and the nature of the melting process with peraluminous magmas formed from hydrous melting of pelitic or semi-pelitic rocks (Frost et al 2001). Johannes and Holtz (1996) have noted that the presence of certain minerals is decisive to ascertain the source characters of granitoid plutons and this holds true for Mylliem granitoids as the presence of modal muscovite and apatite with $>1$ wt. $\%$ normative corundum is indicative of the S-type character and points to a sedimentary origin. Thus, in terms of both petrography and chemistry, the Mylliem granitoids differ significantly from tonalite-trondjhemite-granodiorite suite (Tarney 1976; Arth 1979; Collerson and Bridgwater 1979; Tarney et al 1979) and it is clear that the currently studied granitoids have a source character which is quite distinct from amphibolites/basaltic materials. According to Chappell and White (1974) and Hine et al (1978), the peraluminous, S-type granitoids are most commonly produced by parent melt extraction from metasedimentary source rocks by partial melting. Thus, from the foregoing discussion, it is evident that partial melting of Shillong Group of metasediments (rather than mafic rocks) provides the most viable source material for the Mylliem granitoids.

\subsection{Implications on petrogenesis}

The trends of variation depicted by major element oxides with respect to $\mathrm{SiO}_{2}$ suggest a significant role of fractional crystallization during the course of magmatic evolution. The fall of $\mathrm{Al}_{2} \mathrm{O}_{3}$ with increasing $\mathrm{SiO}_{2}$ clearly indicates the fractionation of feldspar. The decreasing trend of $\mathrm{MgO}$ with increasing $\mathrm{SiO}_{2}$ represents the fractionating behaviour of the parent magma. The variation patterns of trace elements such as $\mathrm{Ba}$, $\mathrm{Sr}$ have been effectively used for evaluating fractional crystallization processes in granites (Mittlefehldt and Miller 1983; Mackenzie et al 1988). In this study, negative correlations depicted by $\mathrm{Ba}$ and $\mathrm{Sr}$ with $\mathrm{SiO}_{2}$ strongly suggest fractionation of plagioclase and $\mathrm{K}$-feldspar in Mylliem porphyritic granites. $\mathrm{Zr}$ vs. $\mathrm{Y}$ shows a positive trend as expected in fractional crystallization processes. The negative $\mathrm{Eu}$ and $\mathrm{Sr}$ anomalies support the contention of early fractionation of plagioclase from the magma by fractional crystallization (Rollinson 1993). The geochemical variations observed for the Mylliem porphyritic granites are in consonance with the idea of fractional crystallization playing a dominant role in the petrogenetic evolution of the Mylliem pluton. Inferences drawn on the basis of geochemical criteria aided by field and petrographic evidences suggest the separation of plagioclase and alkali feldspar as constituent phenocrystal phases due to fractional crystallization. Some critical element ratios can be successfully employed for evaluating the source characteristics and evolutionary trend (Whalen et al 1987). High Rb/Sr, Ba/Sr ratios, high $\mathrm{K} \%$ and relative enrichment of HFSE suggest that the Mylliem porphyritic granites are primarily derived from a felsic source (Rogers and Greenberg 1990) characterized by high K content and relatively low $\mathrm{Ca}$.

\subsection{Implications on tectonic setting}

The mineralogy and chemistry of granitoids serve as effective tools for fingerprinting their tectonic environment (Brown et al 1984; Pearce et al 1984). Mylliem granitoids with characteristic mineralogical and geochemical features can be tectonically discriminated as post-orogenic granites (POG) (Maniar and Piccoli 1989). The tectonic discrimination diagram of Maniar and Piccoli (1989), using $\mathrm{Al}_{2} \mathrm{O}_{3}$ vs. $\mathrm{SiO}_{2}$ as suitable parameters, depicts a post-orogenic setting for the Mylliem granitoids, where all the relevant data-points cluster in the field of POG (figure 9a). Thus, a postorogenic setting for the Mylliem granitoids is envisaged. It has been widely observed that POG are emplaced during the last phase of an orogeny, generally after the cessation of deformation in the region. These granitoids represent the transitional phase of the continental crust undergoing stabilization following the orogenic episode (Maniar and Piccoli 1989). These well-documented observations on $\mathrm{POG}$ are in accord with the conclusions derived from the field evidences in the study area at and around Mylliem which reveal that the Mylliem granitoids have not been affected by regional deformational and metamorphic events. Thus, it is evident that the emplacement of Mylliem pluton is marked by a post-orogenic tectonic environment. In $\mathrm{FeO}^{(t)} /\left(\mathrm{FeO}^{(t)}+\mathrm{MgO}\right)$ vs. $\mathrm{SiO}_{2}$ (figure 9b) and $\mathrm{Na}_{2} \mathrm{O}+\mathrm{K}_{2} \mathrm{O}-\mathrm{CaO}$ vs. $\mathrm{SiO}_{2}$ (figure 9c) diagrams, the Mylliem granitoids occupy the field of Caledonian post-collisional plutons of Ireland and Britain. These Caledonian post-collisional plutons are typified by peraluminous, alkali-calcic, magnesian, post-orogenic granitoids with high potassium content and lack of iron enrichment. Thus, it is inferred that the Mylliem pluton of Shillong Plateau, Northeastern India, 
(a)
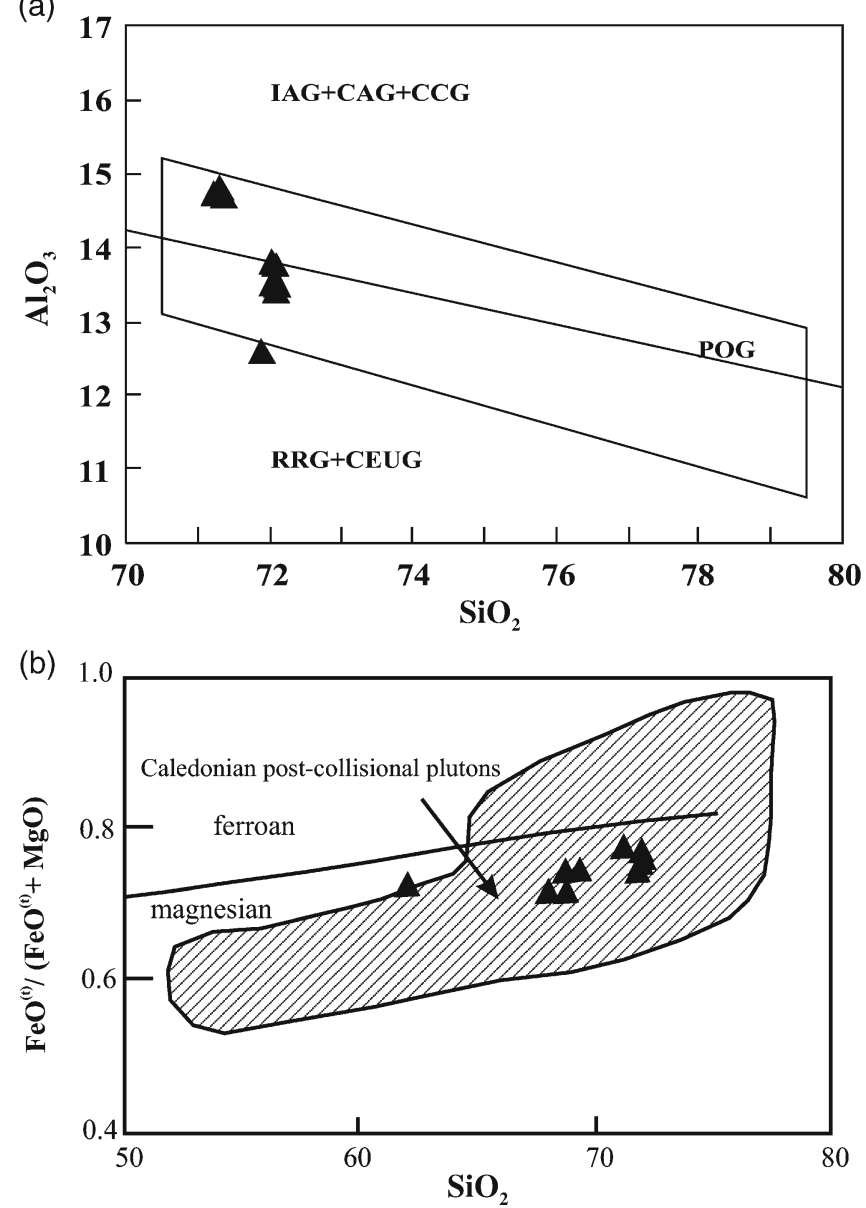

(c)

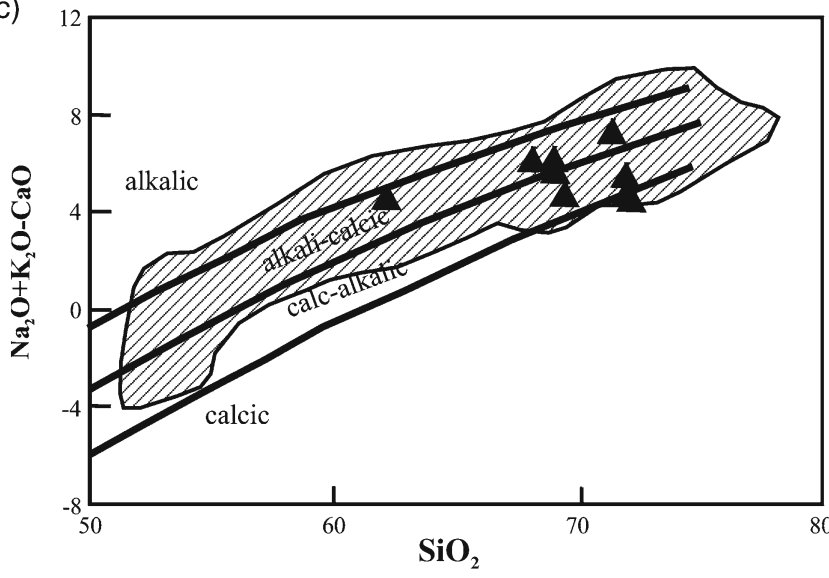

Figure 9. (a) $\mathrm{Al}_{2} \mathrm{O}_{3}$ vs. $\mathrm{SiO}_{2}$ diagram depicting a postorogenic setting (POG) for Mylliem granitoids (Maniar and Piccoli 1989). (b) $\mathrm{FeO}^{(t)} /\left(\mathrm{FeO}^{(t)}+\mathrm{MgO}\right)$ vs. $\mathrm{SiO}_{2}$ diagram showing the plots of Mylliem granitoids in the field of Caledonian post-collisional pluton (Frost et al 2001). (c) $\mathrm{Na}_{2} \mathrm{O}+\mathrm{K}_{2} \mathrm{O}-\mathrm{CaO}$ vs. $\mathrm{SiO}_{2}$ diagram showing the plots of Mylliem granitoids in the field of Caledonian post-collisional pluton (Frost et al 2001).

with peraluminous, magnesian, calc-alkalic to alkali-calcic, S-type characters and post-orogenic tectonic setting are correlatable with the Caledonian post-collosional plutons of Ireland and Britain.

\section{Conclusions}

The Meghalaya Plateau of northeastern India forms the northeastern margin of Neoproterozoic segments signifying the evolving plate boundary at that time. A number of cross-cutting syn- to late-tectonic granite plutons have been described in the Meghalaya Plateau. This study brings out for the first time detailed field relations, petrography and geochemical characters of Mylliem pluton which marks one of the important granitoid plutons in the plateau (Ghosh et al 2005). Field studies indicate that the Mylliem granitoids bear evidences of forceful injection of granitic melt into the neighbouring country rock (Shillong Group of rocks). The Mylliem granitoids contain xenoliths of Shillong Group of metasediments and mafic rocks which serve as further evidence of their intrusive origin. Petrographically the Mylliem granitoids show a compositional spread from granite to granodiorite in the $\mathrm{Q}-\mathrm{A}-\mathrm{P}$ diagram (Streckeisen 1976). Normative An-Or-Ab diagram (O'Connor 1965) discriminates the granitoids to be 'granitic' with a limited compositional range. Critical consideration of their mineralogical, petrological and geochemical characters suggests that the Mylliem granitoids have a distinct peraluminous, S-type affinity. The Shillong Group of rocks has been deduced to be the precursor of the Mylliem granitoids and it has been suggested that partial melting of the Shillong Group of rocks gave rise to melt parental to the Mylliem granitoids. Geochemical signatures characterize the Mylliem Granitoids as POG and they are chemically similar to the Caledonian post-collisional granitoid plutons.

\section{Acknowledgements}

Field work was funded by a research grant given by the Department of Science and Technology (DST), Govt. of India (to JR; Grant No: ESS/16/ 226/2005). The authors are thankful to Tanoy Ganguly, Pritam Saha and Soumyajit Sau for their assistance during field work. The Head, Department of Geology, University of Calcutta and Director, NGRI, Hyderabad provided necessary laboratory facilities. Two anonymous referees provided very critical and useful comments to upgrade the quality of the paper. The authors gratefully acknowledge Prof. Talat Ahmad, Associate Editor, for his valuable comments and fruitful suggestions.

\section{References}

Acharyya A, Ray S, Chaudhuri B K, Basu S K, Bhaduri S K and Sanyal A K 2006 Proterozoic rock suites along 
South Purulia Shear Zone, Eastern India: Evidence for rift-related setting; J. Geol. Soc. India 68 1069-1087.

Acharyya S K, Mitra N D and Nandy D R 1986 Regional geology and tectonic setting of North-East India and adjoining region; Geol. Surv. India Memoir 119 6-12.

Arth J G 1979 Some trace elements in Trondjhemites - their implications to magma genesis and palaeotectonic setting; Trondjhemites, Dacites and Related Rocks; (ed.) Barker F (Amsterdam: Elsevier), 313-345.

Barbarin B 1999 A review of the relationships between granitoid types, their origins and their geodynamic environments; Lithos 46 605-626.

Barker F and Arth J G 1976 Generation of trondjhemite tonalitic liquids and Archaean bimodal trondjhemitebasalt suite; Geology 4 596-600.

Brown G C, Thorpe R S and Webb P C 1984 The geochemical characteristics of granitoid in contrasting areas and comments on magma sources; J. Geol. Soc. London 141 $413-426$.

Chappell B W and White A J R 1974 Two contrasting granite types; Pacific Geol. 8 173-174.

Chatterjee N, Mazumdar A C, Bhattacharya A and Saikia R R 2007 Mesoproterozoic granulites of the ShillongMeghalaya Plateau: Evidence of westward continuation of the Prydz Bay Pan-African suture into Northeastern India; Precamb. Res. 152 1-26.

Collerson K D and Bridgwater D 1979 Metamorphic development of early Archaean tonalitic and trondjhemitic gneisses: Saglek area, Labrador Trondjhemites, Dacites and Related Rocks (ed.) Barker F (Amsterdam: Elsevier), 205-273.

Das Gupta A B and Biswas A K 2000 Geology of Assam; J. Geol. Soc. India, Bangalore, 169p.

Desikachar S V 1974 A review of the tectonic and geological history of eastern India in terms of plate tectonic theory; J. Geol. Soc. India 15 137-149.

Dhar S, Frei R, Kramers J D, Nagler T F and Kochhar $\mathrm{N} 1996 \mathrm{Sr}, \mathrm{Pb}$ and $\mathrm{Nd}$ isotope studies and their bearing on the petrogenesis of the Jalore and Siwana complexes, Rajasthan, India; J. Geol. Soc. India 48 161-170.

Evans P 1964 The tectonic framework of Assam; J. Geol. Soc. India 5 80-96.

Frost B R, Barens C G, Collins W J, Arculus R J, Ellis D J and Frost C D 2001 A geochemical classification for granite rocks; J. Petrol. 42 2033-2048.

Ghosh S, Chakraborty S, Paul D K, Bhalla J K, Bishui P K and Gupta S N 1994 New Rb-Sr isotopic ages and geochemistry of granitoids from Meghalaya and their significance in middle-to-late Proterozoic crustal evolution; Indian Minerals 48 33-44.

Ghosh S, Fallick A E, Paul D K and Potts P J 2005 Geochemistry and origin of Neoproterozoic Granitoids of Meghalaya, Northeast India: Implications for linkage with amalgamation of Gondwana Supercontinent; Gondwana Res. 8(3) 421-432.

Gupta R P and Sen A K 1988 Imprints of the Ninety-East Ridge in the Shillong Plateau, Indian Shield; Tectonophysics 154 335-341.

Hine R, Williams I S, Chappell B W and White A J R 1978 Contrasts between I- and S-type granitoids of the Kosciusco Batholith; J. Geol. Soc. Australia 25 219-234.

Johannes W and Holtz F 1996 Petrogenesis and Experimental Petrology of Granitic Rocks (Heidelberg: Springer).

Kochhar N and Dhar S 1993 The association of hypersolvussubsolvus granites: A study of Malani igneous suite, India; J. Geol. Soc. India 42 449-467.

Krauskopf K 1982 Introduction to Geochemistry, 2nd edn., (New York: Mcgraw Hill Book Company), 611p.
MacDonald R 1966 Manuscript map for the geology of Uganda; Unpublished Report, Department of Land and Surveys, Entebbe, Uganda.

Mackenzie D E, Black L P and Sun S S 1988 Origin of alkali feldspar granites: An example from the Poimena Granite, northeastern Tasmania, Australia; Geochim. Cosmochim. Acta 52 2507-2524.

Maniar P D and Piccoli P M 1989 Tectonic discrimination of granitoids; Bull. Geol. Soc. Amer. 101 635-643.

Mazumdar S K 1976 A summary of the Precambrian geology of the Khasi Hills, Meghalaya; Geol. Surv. India Misc. Publ. 23(2) 311-334.

Mittlefehldt D W and Miller C F 1983 Geochemistry of Sweetwater Wash Pluton, California: Implications for 'anomalous trace' element behaviour during differentiation of felsic magmas; Geochim. Cosmochim. Acta $\mathbf{4 7}$ 109-124.

Nagudi B, Koeberl C and Kurat G 2003 Petrography and geochemistry of the Singo granite, Uganda and implications for its origin; J. African Earth Sci. 36 73-87.

Nandy D R 1980 Tectonic pattern in northeastern India; Indian J. Earth Sci. 7 103-107.

Nandy D R 1981 Tectonic Pattern in NE India - A discussion; Indian J. Earth Sci. 8(1) 82-86.

Nandy D R 1986 Tectonics, seismicity and gravity of Northeastern India and adjoining region; Geol. Surv. India Memoir 119 13-16.

Nandy D R 2001 Geodynamics of northeastern India and the adjoining region; (Calcutta: ACB Publications), 209p.

O'Connor J T 1965 A classification of quartz rich igneous rock based on feldspar ratio; US Geol. Surv. Paper 525(B) 79-89.

Pearce J A, Harris N B W and Tindle A G 1984 Trace element discrimination diagrams for the tectonic interpretation of granitic rocks; J. Petrol. 25 956-983.

Rahman S 1985 Petrochemistry of the Mylliem granite, Khasi Hills, Meghalaya; J. Geol. Soc. India 26(5) 356-359

Rogers J J W and Greenberg J K 1990 Late-orogenic, post-orogenic and anorogenic granites: Distinction by major elements and trace elements chemistry and possible origins; J. Geol. Soc. India 98 291-309.

Rollinson H R 1993 Using Geochemical Data: Evaluation, Presentation, Interpretation (Harlow: Addison Wesley Longman), 352p.

Satyanarayanan M, Balaram V, Gnaneswar Rao T and Rajendra N P 2006 Application of ICP-MS in earth system sciences; J. Geol. Soc. India 68 923-925.

Sen J, Ranganath N, Rathaiah Y V, Sen D B and Kak S N 2009 Petrography and geochemistry of uranium mineralised Precambrian Granitic-Pegmatitic rocks of Mawlait, West Khasi Hills District, Meghalaya; J. Geol. Soc. India 74 639-645.

Shand S J 1943 The Eruptive Rocks, 2nd edn. (New York: John Wiley), 444p.

Singh B N 2007 Petrology and geochemistry of the Mount Abu Granites, Southwestern Rajasthan; J. Geol. Soc. India $69247-252$.

Srivastava R K and Sinha A K 2004 The Early Cretaceous Sung Valley ultramafic-mafic-alkaline-carbonatite complex, Shillong Plateau, Northeastern India: Petrological and genetic significance; Mineral. Petrol. 80 241-263.

Streckeisen A 1976 To each plutonic rock its proper name; Earth Sci. Rev. 12 1-33.

Sun S S and McDonough W F 1989 Chemical and isotopic systematics of oceanic basalts: Implications for mantle composition and processes; In: Magmatism in the Ocean Basins, (eds) Saunders A D and Norry M J, Geol. Soc. London Spec. Publ. 42 313-345. 
Tarney J 1976 Geochemistry of Archaean high-grade gneisses, with implications as to the origin and evolution of the Archaean Crust; The Early History of the Earth (ed.) Windley B F (London: Wiley-Interscience), 405-417.

Tarney J, Weaver B and Drury S A 1979 Geochemistry of Archaean trondjhemitic and tonalitic gneisses from
Scotland and E. Greenland; Trondjhemites, Dacites and Related Rocks (ed.) Barker F (Amsterdam: Elsevier), 275-299.

Whalen J B, Currie K L and Chappell B W 1987 A-type granites: Geochemical characteristics, discrimination and petrogenesis; Contrib. Mineral. Petrol. 95 407-419. 